\title{
DNA-aided identification of Culex mosquitoes (Diptera: Culicidae) reveals unexpected diversity in underground cavities in Austria
}

\author{
Carina Zittra $^{1}$ (D) Otto Moog $^{2} \cdot$ Erhard Christian $^{3} \cdot$ Hans-Peter Fuehrer ${ }^{1}$
}

Received: 13 November 2018 / Accepted: 26 February 2019 / Published online: 27 March 2019

(C) The Author(s) 2019

\begin{abstract}
Subterranean cavities serve as resting places and hibernation shelters for mosquitoes. In Europe, members of the genus Culex are often the most abundant insects on cave walls. Culex pipiens L., the common house mosquito, exists in two physically very similar, yet genetically and ecologically distinct biotypes (or forms, 'f.'), namely Cx. pipiens f. pipiens and Cx. pipiens $\mathrm{f}$. molestus. Autogeny and stenogamy of the latter form have been interpreted as adaptations to underground habitats. The epigean occurrence of the two biotypes and their hybrids was recently examined in Eastern Austria, but the hypogean distribution of the Cx. pipiens complex and morphologically similar non-members such as $C x$. torrentium is unknown. Considering the key role of Culex mosquitoes in the epidemiology of certain zoonotic pathogens, the general paucity of data on species composition and relative abundance in subterranean shelters appears unfortunate.

For a first pertinent investigation in Austria, we collected mosquitoes in four eastern federal states. Based on analyses of the ACE2 gene and the CQ11 microsatellite locus, 150 female and three male mosquitoes of the genus Culex, two females of the genus Culiseta and a single female of the genus Anopheles were determined to species level or below. In our catches, Cx. pipiens f. pipiens exceeded the apparent abundance of the purportedly cave-adapted Cx. pipiens f. molestus many times over. Records of $C x$. hortensis and $C x$. territans, two species rarely collected in Austria, lead us to infer that underground habitats host a higher diversity of culicine mosquitoes than previously thought.
\end{abstract}

Keywords Culex pipiens s. L. · Hybrids $\cdot$ Culex torrentium $\cdot$ Caves $\cdot$ Parietal fauna $\cdot$ Hibernation

\section{Introduction}

Underground spaces such as natural caves, mining galleries, tunnels and culverts (henceforth referred to as 'caves') are resting and hibernation shelters for numerous families of insects, including hematophagous Diptera such as Psychodidae,

Section Editor: David Bruce Conn

Carina Zittra

carina.zittra@vetmeduni.ac.at

1 Institute of Parasitology, Department of Pathobiology, University of Veterinary Medicine Vienna, Veterinaerplatz 1, 1210 Vienna, Austria

2 Institute of Hydrobiology and Aquatic Ecosystem Management, University of Natural Resources and Life Sciences, Gregor-Mendel-Straße 33/DG, 1180 Vienna, Austria

3 Institute of Zoology, University of Natural Resources and Life Sciences, Gregor-Mendel-Straße 33, 1180 Vienna, Austria
Ceratopogonidae and Culicidae (Obame-Nkoghe et al. 2017a; Carvalho et al. 2016).

Mosquitoes (Culicidae) include vectors of human and veterinary pathogens such as arboviruses, haemosporidians and filarioid nematodes (Norris 2004; Schoener et al. 2017; Übleis et al. 2018). Distribution and transmission of these pathogens are regulated through communities of potential vector organisms (Zittra et al. 2017a). About 10\% of the 3500 known mosquito species play a major role in pathogen transmission (Becker et al. 2010; Diniz et al. 2017).

Members of the Culex pipiens complex are critical for the epidemiology of certain viruses that menace public and veterinary health (Brugman et al. 2018). At least, Sindbis and Sindbis-like viruses (Togaviridae), Lednice virus (Bunyaviridae) and Usutu and West Nile virus (Flaviviridae) are primarily transmitted by Culex species in Europe (Becker et al. 2012; Roiz et al. 2012; Fros et al. 2015). Furthermore, persistence of the West Nile virus lineage 2 throughout the winter season in Europe, facilitated by vertical transmission, is strongly linked to this species complex (Rudolf et al. 2017). Heed must be paid to the fact that different host preferences of 
the two $C x$. pipiens forms and the hybrids entail distinct vector competences (Lundström et al. 1990; Vogels et al. 2016). In addition, the two forms exhibit ecological differentiation: Culex pipiens $\mathrm{f}$. pipiens is basically ornithophilic (bird-biting), anautogenous (the female requires a blood meal for egg development) and eurygamous (mates while swarming in a large breeding area), whereas $C x$. pipiens f. molestus is mammalophilic (preferring mammals), autogenous (can lay a first batch of eggs without a blood meal) and stenogamous (mates in restricted space without nuptial flight). Immature stages of both forms are found at epigean sites, whereas in hypogean sites only f. molestus has been recorded so far (Byrne and Nichols 1999). Furthermore, the two biotypes are known to hybridise in areas where they coexist (Zittra et al. 2016), which may result in populations that act as bridge vectors due to their feeding preferences (Hamer et al. 2008; Černý et al. 2011). Previous studies, not only with reference to Austria, mainly focused on epigean urban and wetland habitats, completely neglecting less accessible sites such as natural caves (Lebl et al. 2014; Zittra et al. 2016).

The mosquito species inventory of Austria currently holds 49 species of eight genera (Zittra et al. 2017b). Only a restricted number of these has been reported from both natural and man-made underground cavities in Austria, namely $C x$. pipiens s.l. (recorded in several federal states: Salzburg, Upper Austria, Lower Austria, Vienna, Burgenland, Styria and Carinthia), Cx. hortensis and Ochlerotatus geniculatus (Carinthia), Culiseta annulata (Lower Austria and Burgenland) (Strouhal and Vornatscher 1975) and Uranotaenia unguiculata (Lower Austria) (Rudolf et al. 2015). The Cx. pipiens complex, usually referred to as the common house mosquito, consists of several taxa (Bahnck and Fonseca 2006; Farajollahi et al. 2011). In Austria, only one species of this complex has been confirmed so far: $C x$. pipiens L., with the biotypes Cx.pipiens f. pipiens, Cx. pipiens f. molestus and hybrids of the two (Zittra et al. 2016). A number of Culex species are genetically separated from the $C x$. pipiens complex (Farajollahi et al. 2011), yet morphologically hardly distinguishable in the female sex. In Austria, this pertains to $C x$. torrentium (Zittra et al. 2016).

Mosquitoes differ in their hibernation strategy (Andreadis et al. 2010). While many species hibernate in immature stages, Culex pipiens s.l. is among the mosquitoes that enter hibernacula for resting as non-blood fed, nulliparous and inseminated females. Hibernating parous females seem to experience high mortality (Andreadis et al. 2010).

Since specimens of the genus Culex from underground cavities have seldom been reliably determined to species level or below, the relevance of these shelters with regard to population dynamics and a potential public health risk is hard to assess. So it seems advisable to establish culicid taxa composition and relative abundance in a previously neglected habitat type: the subterranean realm. In this study, we searched into the composition of mosquito assemblages in Austrian caves for the first time, using - in case of genus Culex - molecular tools. We examined whether the presence of $C x$. pipiens is in fact much higher than the presence of any other culicid species, as the catalogue of Austrian cave animals (Strouhal and Vornatscher 1975) suggests, and whether alleged underground-adapted $C x$. pipiens $\mathrm{f}$. molestus are actually more abundant than $C x$. pipiens f. pipiens or hybrids of the two biotypes.

\section{Material and methods}

\section{Mosquito sampling}

From 2015 to 2018 , we collected mosquitoes in 44 caves in eastern Austria. Table 1 gives the basis data of the sampling sites. The sites were selected such as to cover the different types of cave-like habitats scattered over the federal states of Vienna, Lower Austria, Burgenland and Styria, with a geographic focus on the Vienna region. Each locality was sampled one to three times, only cave Schelmenloch was sampled monthly from January 2017 to May 2018. The effort always equated to one person-hour. We used an aspirator for collecting mosquitoes resting on the cave walls. A moistened duster proved efficient for the catch of flying mosquitoes. Small caves were completely screened for mosquitoes, bigger caves from the entrance to well beyond the innermost mosquito sampling spot (in the aphotic zone, if present). The specimens were transported in cooled plastic tubes to the lab, subsequently deep-frozen and kept in the freezer until examination. Mosquitoes were identified morphologically to species or species complex level using the identification key after Becker et al. (2010). Mosquitoes classified as belonging to the $C x$. pipiens complex or $C x$. torrentium were identified subsequently to species level or form level by means of molecular tools.

\section{DNA extraction and molecular identification}

DNA was extracted from single individuals using the DNeasy Blood and Tissue Kit (Qiagen, Hilden, Germany) according to the manufacturer's protocol. In a first step, $C x$. pipiens forms were distinguished from $C x$. torrentium by partial amplification of the ACE2 gene (Smith and Fonseca 2004) using primers ACEpip, ACEpall, ACEtorr and B1246s in standard PCR protocols (Zittra et al. 2016). PCR products were separated using gel electrophoresis targeting $634 \mathrm{bp}(C x$. pipiens forms) and $512 \mathrm{bp}(C x$. torrentium) DNA fragments. Mosquitoes, determined as members of $C x$. pipiens complex, were subsequently identified to biotype level in a second step (Bahnck and Fonseca 2006) using primers CQ11F2, pip CQ11R and mol CQ11R in standard PCR protocols. PCR products were visualised using gel electrophoresis targeting 
Table 1 Name, position and characteristics of the sampling sites

\begin{tabular}{|c|c|c|c|c|c|c|c|c|c|}
\hline Sampling site & Cave \# & $\begin{array}{l}\text { Fed. } \\
\text { prov. }\end{array}$ & Municipality & $\begin{array}{l}\text { Length, } \\
\text { aphotic }(X)\end{array}$ & Alt. & Lat. & Long. & $\begin{array}{l}\text { Vertebrates } \\
\text { present }\end{array}$ & $\begin{array}{l}\text { Visitor } \\
\text { pressure }\end{array}$ \\
\hline Adlersteighöhle & $1915 / 1$ & LA & Maria Enzersdorf & 16 & 255 & 48.084 & 16.276 & & $\mathrm{H}$ \\
\hline Allander Tropfsteinhöhle & $1911 / 2$ & LA & Alland & $177(\mathrm{X})$ & 403 & 48.053 & 16.077 & $\mathrm{~A}$ & $\mathrm{~S}$ \\
\hline Altenburgerhöhle & $2921 / 23$ & LA & Bad Deutsch-Altenburg & $58(\mathrm{X})$ & 154 & 48.140 & 16.908 & & \\
\hline Antonsgrotte & $1912 / 40$ & LA & Baden & $54(\mathrm{X})$ & 298 & 48.011 & 16.229 & & \\
\hline Camaldulensergrotte am Kahlenberg & Artificial & VI & Wien 19 & 9 & 396 & 48.273 & 16.331 & & \\
\hline Durchlass B 1939 Schreiberbach & Artificial & VI & Wien 19 & 27 & 427 & 48.274 & 16.321 & & \\
\hline Durchlass Krapfenwaldbach & Artificial & VI & Wien 19 & 20 & 329 & 48.266 & 16.332 & & \\
\hline Einödhöhle & $1914 / 6$ & LA & Pfaffstätten & 87 & 375 & 48.024 & 16.236 & A & $\mathrm{H}$ \\
\hline Einsiedlerhöhle & $1912 / 4$ & LA & Baden & 14 & 320 & 48.013 & 16.205 & & \\
\hline Excentriqueshöhle & $1915 / 32$ & LA & Kaltenleutgeben & 18 & 348 & 48.122 & 16.222 & & \\
\hline Gainfarnerhöhle & $1911 / 16$ & LA & Bad Vöslau & 25 & 330 & 47.965 & 16.191 & & \\
\hline Grafenlucke III & $2911 / 72$ & BL & Winden am See & 6 & 170 & 47.968 & 16.754 & & $\mathrm{H}$ \\
\hline Grotte Gspöttgraben & Artificial & VI & Wien 19 & 3 & 367 & 48.259 & 16.313 & & \\
\hline Grufthöhle & $1912 / 9$ & LA & Baden & $72(\mathrm{X})$ & 276 & 48.010 & 16.229 & & \\
\hline Guglzipfhöhle & $1869 / 1$ & LA & Berndorf & 16 & 350 & 47.942 & 16.110 & & \\
\hline Güntherhöhle & $2921 / 2$ & LA & Hundsheim & $206(X)$ & 265 & 48.121 & 16.936 & & \\
\hline Höllturmhöhle & $1869 / 7$ & LA & Wöllersdorf & $180(\mathrm{X})$ & 355 & 47.867 & 16.174 & & $\mathrm{H}$ \\
\hline Johannesbachklamm-Höhle & $1861 / 7$ & LA & Würflach & 30 & 440 & 47.780 & 16.040 & & \\
\hline Johannstein-Halbhöhle & $1915 / 24$ & LA & Hinterbrühl & 2 & 410 & 48.085 & 16.184 & & \\
\hline Keller am Nussberg & Artificial & VI & Wien 19 & 4 & 235 & 48.263 & 16.357 & & \\
\hline Kohlröserlhöhle & $1863 / 59$ & LA & Hohe Wand & 14 & 820 & 47.840 & 16.065 & A & $\mathrm{H}$ \\
\hline Kolloweinhöhle & $2911 / 37$ & BL & Müllendorf & 10 & 245 & 47.846 & 16.459 & & \\
\hline Ludlloch & $2911 / 1$ & BL & Winden am See & 93 & 190 & 47.970 & 16.754 & & $\mathrm{H}$ \\
\hline Luftschutzloch & $1869 / 35$ & LA & Pottenstein & 7 & 335 & 47.966 & 16.085 & & \\
\hline Lurgrotte, Peggau & $2836 / 1$ & ST & Peggau & $5975(\mathrm{X})$ & 412 & 47.216 & 15.343 & $\mathrm{~A}$ & $\mathrm{~S}$ \\
\hline Lurgrotte, Semriach & $2836 / 1$ & ST & Semriach & $5975(\mathrm{X})$ & 636 & 47.227 & 15.379 & & $\mathrm{~S}$ \\
\hline Merkensteinhöhle & $1911 / 32$ & LA & Bad Vöslau & $72(\mathrm{X})$ & 446 & 47.982 & 16.133 & & \\
\hline Merkurhöhle & $1917 / 5$ & LA & Kaltenleutgeben & 11 & 326 & 48.123 & 16.217 & & \\
\hline Mittlerer Stollen, Peggauer Wand & Artificial & ST & Peggau & 2 & 440 & 47.209 & 15.347 & & \\
\hline Mühlriegelhöhle & $2911 / 46$ & BL & Purbach & 12 & 174 & 47.920 & 16.675 & & \\
\hline Muldenloch & $1912 / 31$ & LA & Baden & 14 & 325 & 48.013 & 16.228 & & \\
\hline Müllendorferhöhle & $2911 / 30$ & BL & Großhöflein & 10 & 340 & 47.846 & 16.476 & & \\
\hline Nördlicher Stollen, Peggauer Wand & Artificial & ST & Peggau & $2(X)$ & 440 & 47.209 & 15.347 & $\mathrm{~A}$ & \\
\hline Parabluieberghöhle & $1915 / 25$ & LA & Perchtoldsdorf & 6 & 546 & 48.120 & 16.230 & & \\
\hline Räuberhöhle & $1861 / 12$ & LA & Neunkirchen & 30 & 393 & 47.752 & 16.068 & & \\
\hline Römersteinbruch & Artificial & ST & Wagna & $2000(\mathrm{X})$ & 305 & 46.749 & 15.549 & $\mathrm{~A}, \mathrm{~B}$ & \\
\hline Schelmenloch & $1911 / 41$ & LA & Bad Vöslau & 60 & 330 & 47.981 & 16.197 & $\mathrm{~A}, \mathrm{~B}, \mathrm{C}, \mathrm{RD}$ & \\
\hline Schüttkastenhöhle & $1913 / 14$ & LA & Heiligenkreuz & 17 & 314 & 48.054 & 16.129 & & \\
\hline Staffelhöhle & $1912 / 30$ & LA & Baden & 17 & 325 & 48.016 & 16.225 & & \\
\hline Stollen bei der Lourdesgrotte & Artificial & LA & Heiligenkreuz & 17 & 314 & 48.054 & 16.129 & & $\mathrm{H}$ \\
\hline Türkenbrunnen & Artificial & LA & Bad Vöslau & 62 & 530 & 47.985 & 16.124 & & \\
\hline Unteres Türkenloch & $1869 / 83$ & LA & Berndorf & 5 & 340 & 47.942 & 16.111 & & \\
\hline Wasserglurn & $1913 / 12$ & LA & Heiligenkreuz & $57(\mathrm{X})$ & 285 & 48.030 & 16.137 & & \\
\hline Zisterne Maurer Wald & Artificial & VI & Wien 13 & 3 & 350 & 48.274 & 16.237 & & \\
\hline
\end{tabular}

Cave \# = number in the Austrian cave cadastre; Fed. prov. = federal province $(B L$, Burgenland; $L A$, lower Austria; $S T$, Styria, VI, Vienna) Length = total passage length $(\mathrm{m}),(\mathrm{X})=$ aphotic parts present; Alt. = altitude $(\mathrm{m}$ above sea level); Lat. = Latitude; Long. = Longitude; Vertebrates recorded at sampling date(s): $\mathrm{A}=$ Rhinolophus hipposideros, $\mathrm{B}=$ Rhinolophus ferrumequinum, $\mathrm{C}=$ Myotis myotis, $\mathrm{RD}=$ Rana dalmatina $;$ Visitor pressure: $\mathrm{S}=$ show cave (open for guided tours), $\mathrm{H}=$ attraction on a hiking trail (unattended visits are common) 
185 bp (Cx. pipiens f. pipiens) and 241 bp (Cx. pipiens $\mathrm{f}$. molestus) DNA fragments (Bahnck and Fonseca 2006). Fragments (ca. $700 \mathrm{bp}$ ) of mitochondrial cytochrome c oxidase subunit I (COI) of the negative samples were partially amplified using primers H15CuliCOIFw and H15CuliCOIRv (Zittra et al. 2016) in standard protocols, to test for members of similar Culex species that had possibly passed unnoticed through the initial morphology-based sorting. PCR products were subsequently purified and directly sequenced by a commercial company (LGC Genomics, Germany).

\section{Results}

\section{Mosquito identification}

We analysed 150 female and three male mosquitoes of the genus Culex. The male mosquitoes belonged to $C x$. torrentium and were all collected in June and July. Among females, $C x$. torrentium $(n=69)$ was most abundant, followed by $C x$. pipiens f. pipiens $(n=44)$, Culex hortensis $(n=20)$ and the hybrids $C x$. pipiens f. pipiens $\times \mathrm{f}$. molestus $(n=13)$. Culex pipiens f. molestus $(n=3)$ was represented in low apparent abundance. Culex territans $(n=3)$ has been found rarely in natural and artificial subterranean habitats, the likewise rare species $C x$. modestus $(n=1)$ in a single natural cave. In this study, four species, namely $C x$. hortensis, $C x$. territans, $\mathrm{Cx}$. torrentium and a single female of Anopheles maculipennis s.l. were recorded for the first time in subterranean habitats in Austria (Table 2). Females of Culiseta annulata $(n=2)$ were sampled in a natural and an artificial site in Lower Austria.

\section{Mosquito distribution and phenology}

Culex torrentium and Cx. pipiens f. pipiens were found in all federal states in artificial and natural subterranean habitats, single individuals of $C x$. pipiens f. molestus in Burgenland and Lower Austria at natural sites, hybrids of the two forms in Burgenland, Lower Austria and Styria, mainly in natural caves. Culex hortensis was found in Lower Austria and Vienna, a single $C x$. territans in Lower Austria. Male $C x$. torrentium were found in a natural cave as well as in a tunnel in Lower Austria.

Mosquitoes were abundant in the twilight zone near the entrance and decreased towards the inner reaches. Maximum abundance was determined in autumn. The number of individuals increased in September and decreased after a peak in October (Table 3). Mosquitoes were absent at the study sites in August.

\section{Discussion}

Previous observations in Lower Austrian caves (Fritsch 1992; Wurzenberger 1996) indicate that mated female mosquitoes enter caves for hibernation from late summer on. After abundance peaks in September or October, the number of individuals drops during winter due to mortality. This conforms to our results. We found females from September to May with highest abundance in September and October. The males were collected in June and July. This proves that caves can serve as resting places also for male mosquitoes, although at another season.

Table 2 Mosquitoes (number of individuals) sampled between 2015 and 2018 per month

\begin{tabular}{|c|c|c|c|c|c|c|c|c|c|c|c|}
\hline Month & An. mac. s.l. & Cs. ann. & Cx. hor. & Cx. mod. & Cx. ter. & Cx. tor. & Cx. pip. f. mol. & Cx. pip. f. pip. & Hybrid & Excluded & Total \\
\hline Jan & & & 7 & & & 6 & & & & 1 & 14 \\
\hline Feb & & & 4 & & & 5 & & 3 & & 7 & 19 \\
\hline Mar & & & & & & 2 & & 1 & 3 & 1 & 7 \\
\hline Apr & & & 1 & & 1 & & & 1 & 2 & 7 & 12 \\
\hline May & & & & & & & & & & 1 & 1 \\
\hline Jun & & & & & & 2 & & & & & 2 \\
\hline Jul & 1 & & & & & 2 & & & & 1 & 4 \\
\hline Aug & & & & & & & & & & & 0 \\
\hline Sept & & & 1 & & 1 & 6 & & 2 & & 4 & 14 \\
\hline Oct & & & 3 & & & 26 & 2 & 26 & 7 & 26 & 90 \\
\hline Nov & & & & & & 17 & 1 & 11 & 1 & 22 & 52 \\
\hline Dec & & 2 & 4 & 1 & 1 & 3 & & & & 7 & 18 \\
\hline Total & 1 & 2 & 20 & 1 & 3 & 69 & 3 & 44 & 13 & 77 & 233 \\
\hline
\end{tabular}

An. mac. s.1. = Anopheles maculipennis sensu lato, Cs. ann. = Culiseta annulata, Cx. hor. $=$ Culex hortensis, Cx. mod. $=$ Culex modestus, Cx. ter. $=$ Culex territans, Cx. tor. $=$ Cx. torrentium, Cx. pip. f. pip. $=$ Culex pipiens form pipiens, Cx. pip. f. mol. $=$ Culex pipiens form molestus 
Table 3 Mosquitoes (number of individuals) sampled between 2015 and 2018 per federal state. Abbreviations as in Table 2

\begin{tabular}{|c|c|c|c|c|c|c|c|c|c|c|c|}
\hline Federal state & An. mac. s.l. & Cs. ann. & Cx. hor. & Cx. mod. & Cx. ter. & Cx. tor. & Cx. pip. f. mol. & Cx. pip. f. pip. & Excl. & Hybrid & Total \\
\hline Burgenland & & & & & & 2 & 1 & 9 & 26 & 7 & 45 \\
\hline Lower Austria & 1 & 2 & 19 & 1 & 3 & 46 & 2 & 26 & 41 & 5 & 146 \\
\hline Styria & & & & & & 2 & & 7 & 1 & 1 & 11 \\
\hline Vienna & & & 1 & & & 19 & & 2 & 9 & & 31 \\
\hline Total & & 2 & 20 & 1 & 3 & 69 & 3 & 44 & 77 & 13 & 233 \\
\hline
\end{tabular}

The composition of the Cx. pipiens complex in subterranean habitats reflects the observed species composition in Austrian overground habitats: $C x$. pipiens f. pipiens is most abundant, followed by hybrids and $C x$. pipiens f. molestus (Zittra et al. 2016). Since Cx. pipiens f. molestus is described to be adapted to subterranean life (Byrne and Nichols 1999), we had expected a higher proportion of this form. Our results suggest, however, that subterranean habitats do not host significant numbers of the biotype molestus. It seems that the two forms are equally inclined to spend winter dormancy in caves. Further investigations in extended caves with a zone of perfect darkness, the aphotic zone and steady climate should put this statement to the proof. At the same time, the distribution of the two biotypes along the light and climate gradients could be determined.

The high abundance and frequent occurrence of $C x$. torrentium is new for Austria, but the species has been reported as a winter guest in underground habitats of other European countries: Dobat $(1975,1978)$ and Weber $(1989,1991,1995)$ published several findings in Germany; records in Norway (Kjaerandsen 1993), Sweden (Jaenson 1987) and Slovakia (Moravčík 1976) were compiled by Dvořák (2014). However, these determinations are questionable, since females of $C x$. torrentium are morphologically indistinguishable from females of the $C x$. pipiens complex. In our investigation, $C x$. torrentium, an often neglected, mainly ornithophilic mosquito species, had the highest apparent abundance in natural as well as in artificial cavities.

Combining our results with literature, seven of the 49 culicid species currently known from Austria have been recorded in subterranean habitats so far: Anopheles maculipennis s.l, Cx. torrentium, Cx. pipiens (with the biotypes $C x$. pipiens f. pipiens and $C x$. pipiens f. molestus), $C x$. hortensis, Cx. territans, Culiseta annulata and Ochlerotatus geniculatus (Zittra et al. 2017b; Strouhal and Vornatscher 1975). Uranotaenia unguiculata, a potential vector of the West Nile virus (Rudolf et al. 2015), was not retrieved in this study, although the species is present in Austria and able to hibernate in caves.

Mosquitoes usually start entering hibernacula in early autumn, but our results demonstrate that natural and man-made subterranean shelters are also used as resting places during most of the year. The source of the supposedly underground- adapted biotype molestus remains to be clarified. Our data in combination with previously published results (Zittra et al. 2017a) indicate that caves are neither overly significant for its occurrence, nor serve as hotspots of hybridization. Therefore, we propose that this biotype naturally occurs in low abundance in Eastern Austria. However, population genetics should be conducted to assess whether pipiens $\times$ molestus hybrids contribute to overall population dynamics of the pipiens complex, and to elucidate the population structure within the pipiens complex.

Three mosquito species rated as rare, viz. $C x$. torrentium, $C x$. hortensis and $C x$. territans, were collected during this study. Individual numbers of the latter two species are too low to detect any correlation with overground abundance. The three species are generally hard to come by. A common problem in mosquito ecology is under-estimation of certain species when carbon dioxide traps are used (Beck et al. 2003; Zittra et al. 2017a). It seems that mainly non-mammalophilic species are underrepresented in surveillance studies due to the low attractiveness of these standard traps (Zittra et al. 2017a). The high numbers of $C x$. torrentium in the caves are therefore quite unusual as this species is typically collected in much lower proportions (Zittra et al. 2016). We assume that these relative high abundances in caves might be due to a species-specific preference for resting and hibernating in subterranean shelters. Indeed, several species of the genera Culex, Culiseta, Anopheles and Uranotaenia are known to use caves as places for hibernation or as resting sites (Trájer et al. 2018). On the other hand, we collected low numbers of $C x$. territans and $C x$. hortensis, both likely non-mammalophilic, that are also described as using dark and cool places as daytime resting sites. Generally, little is known about these taxa as they are rarely collected (Zittra and Waringer 2015; Zittra et al. 2016, 2017b). Sophisticated trapping devices might be necessary to capture and investigate such rarely collected, yet not necessarily rare species (Camp et al. 2018). The species-rich genera Aedes and Ochlerotatus mainly hibernate in their immature stages (Becker et al. 2010) and were therefore, as expected, not recorded in this study. The absence of Uranotaenia species at the studied sites possibly relates to their limited distribution in Burgenland, near Lake Neusiedl (Lebl et al. 2014; Camp et al. 2018), while there are only single records in other federal states (Lebl et al. 2015; Zittra et al. 2017). 
Since tourism and modern leisure behaviour make cave visits increasingly popular, pathogens transmitted by caveassociated mosquitoes have become a topic of research, especially in tropical regions (Obame-Nkoghe et al. 2017b; Wiwanitkit 2018). In Austria, 33 out of 16,000 surveyed caves run as show caves (Oedl and Spötl 2016), but many more subterranean sites are well-frequented local attractions without regular guiding service. In Central European caves, the hazard of a mosquito-borne infection is small, as culicids are using caves mainly for resting or hibernation. Reports on mosquito attacks in caves are rare. This is in contrast to subways and similar subterranean habitats in cities (Byrne and Nichols 1999) where the environment does not fully comply with cave conditions.

Our results corroborate the importance of natural and manmade underground cavities as hibernation sites for Culex species and demonstrate the significance of such habitats as resting places. Subterranean shelters house a more diverse mosquito assemblage than previously inferred from literature data. We found that the composition of underground assemblages of the Culex pipiens complex reflects the composition in overground habitats, without proportional increase of $C x$. pipiens f. molestus in the caves. The high proportions of $C x$. torrentium are surprising but can be related to the ecology of the species. Further rare species in our material additionally suggest the inclusion of caves in mosquito surveillance programs.

Acknowledgements We are thankful to Bita Shahi Barogh for her indispensable support in the laboratory. The authors thank Ulla Brandstätter, Melitta Christian, Petra Christian, Karl Mitterer, Alexander Mrkvicka, Alexander Reischütz, Erich Schneider and Michaela Zemanek for their strong support in capturing the mosquitoes.

Data accessibility DNA sequences: GenBank accession numbers MH807264-MH807266.

Author contributions $\mathrm{CZ}$ performed the morphological and molecular identification of the mosquitoes and compiled the manuscript, $\mathrm{OM}$ and EC performed the mosquito sampling and facilitated the access to the subterranean sampling sites. $\mathrm{CZ}, \mathrm{CE}$ and $\mathrm{OM}$ designed the study. OM assisted in the morphological identification. HPF performed the sequence analysis and the molecular work. All authors read and improved the manuscript.

Funding information Open access funding provided by University of Veterinary Medicine Vienna. Financial support was partly provided by the Austrian Federal Ministry of Education, Science and Research via an ABOL (Austrian barcode of Life; www.abol.ac.at) associated project within the framework of the 'Hochschulraum-Strukturmittel' Funds.

\section{Compliance with ethical standards}

Conflict of interest The authors that they have no conflict of interest.

Open Access This article is distributed under the terms of the Creative Commons Attribution 4.0 International License (http:// creativecommons.org/licenses/by/4.0/), which permits unrestricted use, distribution, and reproduction in any medium, provided you give appropriate credit to the original author(s) and the source, provide a link to the Creative Commons license, and indicate if changes were made.

\section{References}

Andreadis TG, Armstrong PM, Bajwa WI (2010) Studies on hibernating populations of Culex pipiens from a West Nile virus endemic focus in New York City: parity rates and isolation of West Nile virus. J Am Mosq Control Assoc 26(3):257-264. https://doi.org/10.2987/106004.1

Bahnck CM, Fonseca DM (2006) Rapid assay to identify the two genetic forms of Culex (Culex) pipiens L. (Diptera: Culicidae) and hybrid populations. Am J Trop Med Hyg 75(2):251-255. https://doi.org/ 10.4269/ajtmh.2006.75.2.0750251

Beck M, Galm M, Weitzel T, Fohlmeister V, Kaiser A, Arnold A, Becker N (2003) Preliminary studies in the mosquito fauna of Luxembourg. Eur Mosq Bull 14:21-24

Becker N, Petrić D, Zgomba M, Boase C, Madon M, Dahl C, Kaiser A (2010) Mosquitoes and their control. Springer, Berlin

Becker N, Jöst H, Ziegler U, Eiden M, Höper D, Emmerich P, FichetCalvet E, Ehichioya DU, Czajka C, Gabriel M (2012) Epizootic emergence of Usutu virus in wild and captive birds in Germany. PLoS One 7:e32604. https://doi.org/10.1371/journal.pone.0032604

Brugman VA, Hernández-Triana LM, Medlock JM, Fooks AR, Carpenter S, Johnson N (2018) The role of Culex pipiens L. (Diptera: Culicidae) in virus transmission in Europe. Int $J$ Environ Res Public Health 15:389. https://doi.org/10.3390/ijerph15020389

Byrne K, Nichols RA (1999) Culex pipiens in London underground tunnels: differentiation between surface and subterranean populations. Heredity 82(1):7-15. https://doi.org/10.1038/sj.hdy.6884120

Camp JV, Bakonyi T, Soltész Z, Zechmeister T, Nowotny N (2018) Uranotaenia unguiculata Edwards, 1913 are attracted to sound, feed on amphibians, and are infected with multiple viruses. Parasit Vectors 11(1):456. https://doi.org/10.1186/s13071-018-3030-2

Carvalho G, Brazil RP, Rêgo FD, Ramos M, Zenóbio A, Filho JD (2016) Molecular detection of Leishmania DNA in wild-caught phlebotomine sand flies (Diptera: Psychodidae) from a cave in the state of Minas Gerais, Brazil. J Med Entomol 54(1):196-203. https://doi.org/10.1093/jme/tjw137

Černý O, Votýpka J, Svobodová M (2011) Spatial feeding preferences of ornithophilic mosquitoes, blackflies and biting midges. J Med Entomol 25(1):104-108. https://doi.org/10.111//j.1365-2915.2010. 00875.x

Diniz DFA, de Albuquerque CMR, Oliva LO, de Melo-Santos MAV, Ayres CFJ (2017) Diapause and quiescence: dormancy mechanisms that contribute to the geographical expansion of mosquitoes and their evolutionary success. Parasit Vectors 10:310. https://doi.org/ 10.1186/s13071-017-2235-0

Dobat K (1975) Die Höhlenfauna der Schwäbischen Alb. Abhandlungen zur Karst- und Höhlenkunde, Reihe D, 2: 260-381

Dobat K (1978) Die Höhlenfauna der Fränkischen Alb. Abhandlungen zur Karst- und Höhlenkunde, Reihe D, 3: 1-238

Dvořák L (2014) Invertebrates found in underground shelters of western Bohemia. I. Mosquitoes (Diptera: Culicidae). J Eur Mosq Control Assoc 32:27-32

Farajollahi A, Fonseca DM, Kramer LD, Kilpatrick AM (2011) "Bird biting” mosquitoes and human disease: a review of the role of Culex pipiens complex mosquitoes in epidemiology. Infect Genet Evol 11(7):15771585. https://doi.org/10.1016/j.meegid.2011.08.013

Fritsch G (1992) Räumliche und zeitliche Verteilungsmuster der Wandfauna der Güntherhöhle Hundsheimer Berg / Niederösterreich. Master thesis, University of Vienna, $60 \mathrm{pp}$. 
Fros JJ, Vogels CB, Gaibani P, Sambri V, Martina BE, Koenraadt CJ, van Rij RP, Vlak JM, Takken W, Pijlman GP (2015) Comparative Usutu and West Nile virus transmission potential by local Culex pipiens mosquitoes in North-Western Europe. One Health 2015:31-36. https://doi.org/10.1016/j.onehlt.2015.08.002

Hamer GL, Kitron UD, Brawn JD, Loss SR, Ruiz MO, Goldberg TL, Walker ED (2008) Culex pipiens (Diptera: Culicidae): a bridge vector of West Nile virus to humans. J Med Entomol 45(1):125-128. https://doi.org/10.1603/0022-2585(2008)45[125:cpdcab]2.0.co;2

Jaenson TG (1987) Overwintering of Culex mosquitoes in Sweden and their potential as reservoirs of human pathogens. Med Vet Entomol 1(2):151-156. https://doi.org/10.1111/j.1365-2915.1987.tb00336.x

Kjaerandsen J (1993) Diptera in mines and other cave systems in southern Norway. Entomol Fenn 4:151-160

Lebl K, Zittra C, Silbermayr K, Obwaller A, Berer D, Brugger K, Walter M, Pinior B, Fuehrer HP, Rubel F (2014) Mosquitoes (Diptera: Culicidae) and their relevance as disease vectors in the city of Vienna, Austria. Parasitol Res 114(2):707-713. https://doi.org/10. 1007/s00436-014-4237-6

Lundström JO, Turell M, Niklasson B (1990) Effect of environmental temperature on the vector competence of Culexp pipiens and $C x$. torrentium for Ockelbo virus. Am J Trop Med Hyg 43(5):534-542. https://doi.org/10.4269/ajtmh.1990.43.534

Moravčík P (1976) Ročná dynamika niektorých čeladí Dipter (Culicidae, Heleomyzidae) vo vybraných jaskyniach Liptova [Year dynamics of some dipteran families (Culicidae, Heleomyzidae) in selected caves of the Lipton region]. Unpubl. diploma thesis (Faculty of Biology, Komenius University, Bratislava), 60 pp., Appendix 21 pp.

Norris DE (2004) Mosquito-borne diseases as a consequence of land use change. Ecohealth 1:19-24. https://doi.org/10.1007/s10393-0040008-7

Obame-Nkoghe J, Leroy E, Paupy C (2017a) Diversity and role of cavedwelling hematophagous insects in pathogen transmission in the Afrotropical region. Emerg Microbes Infect 6(4):1-6. https://doi. org/10.1038/emi.2017.6

Obame-Nkoghe J, Rahola N, Ayala D, Yangari P, Jiolle D, Allene X, Bourgarel M, Maganga GD, Berthet N, Leroy EM, Paupy C (2017b) Exploring the diversity of blood-sucking Diptera in caves of Central Africa. Sci Rep 7(1):250. https://doi.org/10.1038/s41598017-00328-Z

Oedl F, Spötl C (2016) Schauhöhlen. In Spötl C, Plan L, Christian E (eds.): Höhlen und Karst in Österreich. Linz, Oberösterreichisches Landesmuseum, 367-376

Roiz D, Vazquez A, Rosà R, Muñoz J, Arnoldi D, Rosso F, Figuerola J, Tenorio A, Rizzoli A (2012) Blood meal analysis, flavivirus screening, and influence of meteorological variables on the dynamics of potential mosquito vectors of West Nile virus in northern Italy. J Vector Ecol 37(1):20-28. https://doi.org/10.1111/j.1948-7134. 2012.00196.x

Rudolf I, Šebesta O, Straková P, Betášová L, Blažejová H, Venclíková K et al (2015) Overwintering of Uranotaenia unguiculata adult females in Central Europe: a possible way of persistence of the putative new lineage of West Nile virus? J Am Mosq Control Assoc 31(4):364-365. https://doi.org/10.2987/8756-971x-31.4.364

Rudolf I, Betášová L, Blažejová H, Venclíková K, Straková P, Šebesta O, Mendel J, Bakonyi T, Schaffner F, Nowotny N, Hubálek Z (2017)
West Nile virus in overwintering mosquitoes, Central Europe. Parasit Vectors 10:452. https://doi.org/10.1186/s13071-017-2399-7

Schoener E, Uebleis SS, Butter J, Nawratil M, Cuk C, Flechl E et al (2017) Avian Plasmodium in eastern Austrian mosquitoes. Malar J 16(1):389. https://doi.org/10.1186/s12936-017-2035-1

Smith JL, Fonseca DM (2004) Rapid assays for identification of members of the Culex (Culex) pipiens complex, their hybrids, and other sibling species (Diptera: Culicidae). The Am J Trop Med Hyg 70(4): 339-345. https://doi.org/10.4269/ajtmh.2004.70.339

Strouhal H, Vornatscher J (1975) Katalog der rezenten Höhlentiere Österreichs. Ann Naturhist Mus Wien 79:401-542

Trájer A, Schoffhauzer J, Padisák J (2018) Diversity, seasonal abundance and potential vector status of the cave-dwelling mosquitoes (Diptera: Culicidae) in the Bakony-Balaton region. Acta Zoologica Bulgarica 70(2):247-258

Übleis SS, Cuk C, Nawratil M, Butter J, Schoener E, Obwaller AG et al (2018) Xenomonitoring of mosquitoes (Diptera: Culicidae) for the presence of filarioid helminths in eastern Austria. Can J Infect Dis Med Microbiol 2018:1-6. https://doi.org/10.1155/2018/9754695

Vogels CB, Fros JJ, Göertz GP, Pijlman GP, Koenraadt CJ (2016) Vector competence of northern European Culex pipiens biotypes and hybrids for West Nile virus is differentially affected by temperature. Parasit Vectors 9(1):393. https://doi.org/10.1186/s13071-016-1677-0

Weber D (1989) Die Höhlenfauna und -flora des Höhlenkatastergebietes Rheinland-Pfalz/Saarland, 2. Teil. Abhandlungen zur Karst- und Höhlenkunde, 23. München

Weber D (1991) Die Evertebratenfauna der Höhlen und künstlichen Hohlräume des Katastergebietes Westfalen einschließlich der Quellen- und Grundwasserfauna. Abhandlungen zur Karst- und Höhlenkunde, 25. München

Weber D (1995) Die Höhlenfauna und -flora des Höhlenkatastergebietes Rheinland-Pfalz/Saarland, 3. Teil. Abhandlungen zur Karst- und Höhlenkunde, 29. München

Wiwanitkit V (2018) Cave associated infection: an issue in tropical medicine. J Health Sci Med Res 36(3):167-170. https://doi.org/10. 31584/jhsmr.2018.36.3.14

Wurzenberger J (1996) Die parietale Assoziation des Schelmenloches bei Baden /N.Ö. Master thesis, University of Vienna, 95 pp

Zittra C, Flechl E, Kothmayer M, Vitecek S, Rossiter H, Zechmeister T, Fuehrer H (2016) Ecological characterization and molecular differentiation of Culex pipiens complex taxa and Culex torrentium in eastern Austria. Parasit Vectors 9(1):197. https://doi.org/10.1186/ s13071-016-1495-4

Zittra C, Vitecek S, Obwaller AG, Rossiter H, Eigner B, Zechmeister T et al (2017a) Landscape structure affects distribution of potential disease vectors (Diptera: Culicidae). Parasit Vectors 10(1):205. https://doi.org/10.1186/s13071-017-2140-6

Zittra C, Lechthaler W, Mohrig W, Car M, (2017b) Diptera: Culicidae. In Moog O, Hartmann A (eds.): Fauna Aquatica Austriaca, 3. Edition. BMLFUW, Vienna

Publisher's note Springer Nature remains neutral with regard to jurisdictional claims in published maps and institutional affiliations. 